\section{Abstract}

\title{
Linking the Acadian Orogeny with Organic-Rich Black Shale Deposition: Evidence from
}

\author{
the Marcellus Shale
}

The trace and rare earth elements (REE) analyses were conducted on samples collected from a 30-m core of the Marcellus Shale obtained from Greene County, southwestern Pennsylvania. Our results suggest that organic matter enrichment trends in the Marcellus Shale can be directly linked with the Acadian Orogeny. The Acadian Orogeny has been recognized as a main sediment source for the Marcellus Shale. Synthesis of tectonic history and recent ash bed geochronology, reveals that deposition of the organic carbon-rich (OR) zone (characterized by TOC $>4 \%$; located between $2393 \mathrm{~m}$ and $2406.5 \mathrm{~m}$ core depth) in the studied Marcellus Shale core was coincident with tectonically active and magmatic quiescent period of the Acadian orogeny (ca. 395-380 Ma). This time period also corresponds to the highest rate of mountain building in the Acadian Orogeny. The light rare earth (LREE) and selected trace elemental (e.g., Ta, Cs) composition of the OR zone sediments is similar to that of the bulk continental crust, supporting the lack of magmatic activity in the source area (i.e. Acadian Orogeny). In contrast, subsequent deposition of the organic carbon-poor (OP) sediments (characterized by TOC $<4 \%$; located between $2376 \mathrm{~m}$ and $2393 \mathrm{~m}$ core depth) in the upper Marcellus Shale occurred synchronously with a magmatic active phase (ca. 380-370 Ma) during the Acadian orogeny. The OP zone sediments have LREE and trace elemental composition similar to the average of the upper continental crust, suggesting intrusion of granodiorite rocks during a magmatic active period of Acadian Orogeny. The temporal and geochemical correlation between the Acadian orogenesis and the Marcellus deposition provide evidence for the role of tectonism in the enrichment of organic matter in the Marcellus Shale. 


\section{Introduction}

Due to the recent boom in shale gas production in the Appalachian basin, United Sates,

26

27 the natural gas-rich Marcellus Shale has drawn tremendous attention from the geoscience community. Well production data have shown that the 'gas-rich' zones within the Marcellus Shale are often associated with high total organic carbon (TOC) content. Many studies have tried to understand the mechanisms of organic matter enrichment during black shale deposition (e.g., Ettensohn, 1985; Pedersen and Calvert, 1990; Sageman et al., 2003; Rimmer et al, 2004; Ver Straeten., 2009, 2010; Chen et al., 2015; Chen and Sharma, 2016). It has long been recognized that enrichment of organic matter in fine-grained sediments such as shale is directly affected by several processes like 1) rate of sediment input, 2) water column redox conditions; and 3) primary productivity (e.g., Pederson and Calvert, 1990; Werne et al., 2002; Sageman et al., 2003; Rimmer et al., 2004; Lash and Blood, 2014). In addition, a recent study Chen and Sharma (2016) also suggested that nutrient recycling is driven by alternating water column redox conditions might have also played a key role in the formation of the organic-rich zone in the Marcellus Shale.

However, the underlying mechanism that caused the widespread deposition of black shale in the Acadian foreland basin is still debated. The tectonostratigraphic model proposed by Ettensohn (1985) suggests that deposition of organic carbon (OC)-rich black shales in the Appalachian basin was controlled by tectonic forces of Acadian orogeny, whereas recent studies demonstrate that global sea-level change may have also played a key role (Arthur, 2005; Sageman et al., 2003; Werne et al., 2002). Thus, the objective of this study is to understand the processes (i.e., tectonism) that might have contributed to this widespread deposition of black shale in the Acadian foreland basin. Further, we tried to establish direct linkage (i.e., temporal 
47 and geochemical correlations) between these processes and sedimentary records preserved in the 48 Marcellus Shale in our study area.

51 shallow open marine environments with little to no terrigenous clastic input. The onset of the

52 Acadian orogeny led to crustal bending and subsidence within the adjacent foreland basin

53 (Ettensohn, 1985). Subsequent cratonward advancement of the Acadian orogenic front created

54 fold-thrust sheets that uplifted the old sedimentary and low-grade metamorphic rocks in the

55 Acadian mountain and recycled them to the foreland basin (Ettensohn, 1985; Ver Straeten, 2009).

56 High erosion rates during the active orogenesis generate high sedimentation rates and low

57 oxygen availability, resulting in anoxic bottom water conditions and enhanced organic carbon

58 burial (Galy et al., 2007). Although several modifications have been made to this model (e.g.,

59 Bradley, 2000; Ettensohn, 1987), it still remains one of the most widely accepted model as it

60 explains some basic observations in the sedimentary records. However, recent studies suggest

61 that global sea-level change may have also played a key role in organic matter enrichment

62 because deposition of OC-rich black shales in the Appalachian Basin generally coincides with

63 the periods of global sea-level transgressions (Arthur, 2005; Sageman et al., 2003; Werne et al.,

64 2002). It is well known that global sea-level rise can mitigate sediment 'dilution' effect by

65 reducing terrestrial weathering and the amount of sediments transported into the basin (e.g.,

66 Sageman et al., 2003; Werne et al., 2002). Rising of sea-level reduces the efficiency of water-

67 column mixing, creating more reducing bottom water conditions that are favorable for organic 
In terms of the tectonic control on black shale accumulation, a key piece of information

70 still missing is a direct linkage between tectonics and sedimentary records that are independent

71 of other variables (e.g., global sea-level change). Recent studies of volcanic ash layers in the

72 Appalachian Basin reveal that the development of the Acadian Orogeny and the associated

73 foreland basin during Early-Middle Devonian time was associated with multiple phases of

74 volcanism/magmatism within the Acadian mountain (Murphy et al., 1999; Ver Straeten, 2005,

75 2008). Based on the relative intensity of magmatism, the Acadian orogeny can be subdivided

76 into three magmatic stages: a magmatic active period that lasted from early Emsian to lower-

77 middle Eifelian ( 400-395 Ma), followed by a relatively magmatic quiescent period between

$78 \sim 395 \mathrm{Ma}$ and $\sim 380 \mathrm{Ma}$ which was then succeeded by another magmatic active period from $\sim 380$

79 Ma to $~ 370$ Ma (Murphy et al., 1999).

Signals of the proposed Acadian magmatism were recorded by sediments deposited in the

81 adjacent foreland basin (Hosterman and Whitlow, 1981). It has been found that the Middle to

82 Late Devonian marine shales of the Appalachian Basin contain abundant smectite which is

83 interpreted to be derived from weathered volcanic clast and phenocrystals, indicating a

84 significant sediment contribution from igneous sources (Hosterman and Whitlow, 1981). If

85 representative, the shale strata deposited within the Appalachian Basin may likely record the

86 geochemical signals (e.g., trace and rare earth element content) of the Acadian magmatism. It has

87 been shown that partial melting of crustal rocks during magmatism can cause enrichment of light

88 rare earth elements (i.e., La-Sm) in the newly formed magma (Liping and McKay, 1989), which

89 later migrates upward toward the surface, forming intrusive or extrusive igneous rocks.

90 Therefore, the newly formed igneous rocks should bear REE composition different from the

91 source region. Weathering of these rocks would then transport the REE signals into the adjacent 
92 sedimentary basin. There is little fractionation of REE during weathering of parent rocks or

93 during subsequent sediment transportation (e.g., Condie, 1991). As such, it is obvious that the

94 REE compositions of fine-grained rocks formed by deposition and lithification of these

95 weathered sediments would resemble the REE signature of their sediment source. Therefore, we hypothesized that if the OC-rich black shale deposition in the Appalachian foreland basin was

97 directly related to the Acadian orogeny, we should observe a correlation between the Acadian magmatic signals and organic carbon enrichment in the shale.

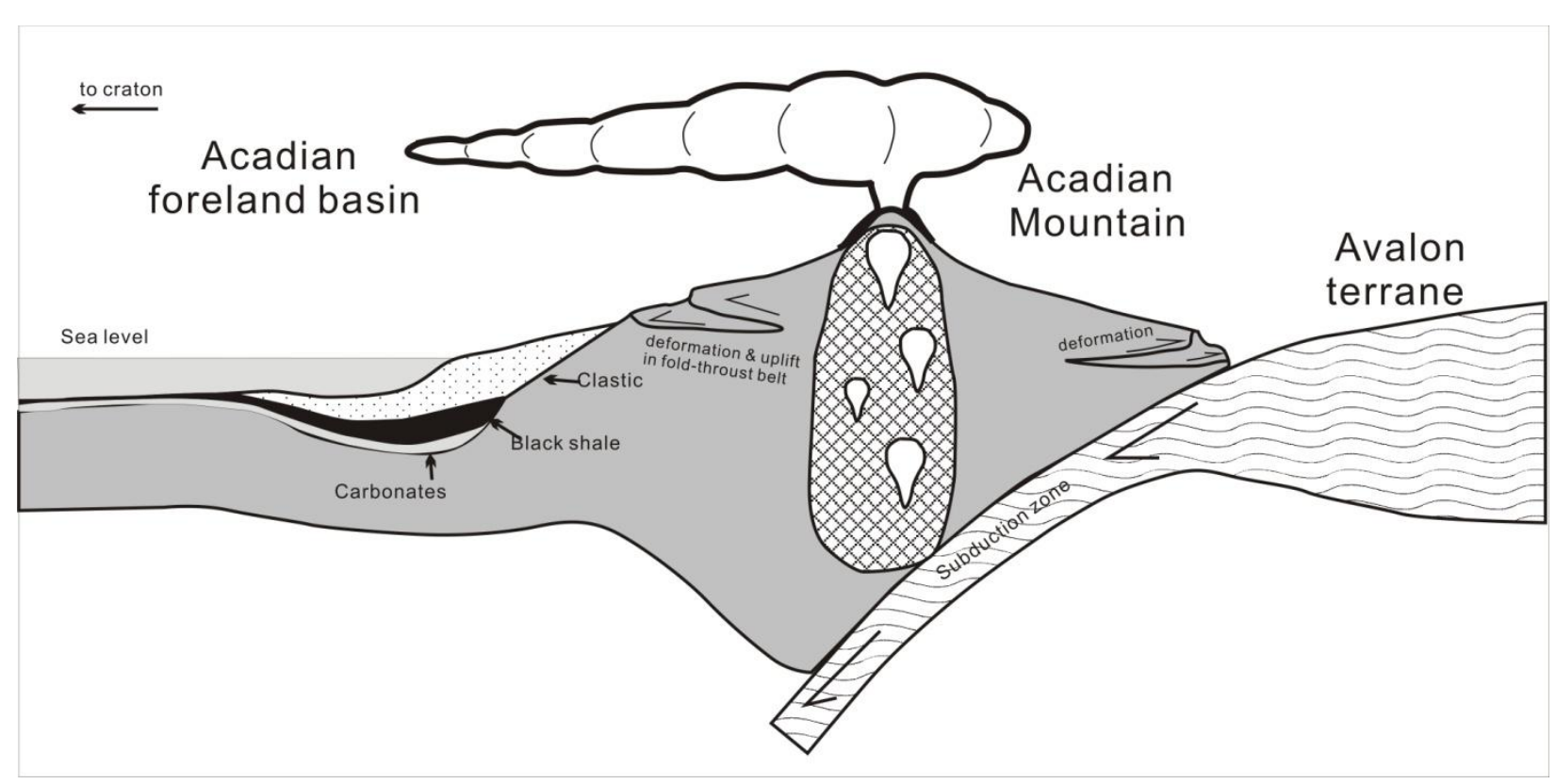

Figure 1: A tectonic model of the Acadian Orogen and the associated foreland basin (modified from Ver Straeten, 2009). samples collected from a well core from southwestern Pennsylvania, USA. Shale samples are grouped as organic-rich (OR) and organic-poor $(\mathrm{OP})$ categories with the purpose of establishing the possible link between the Acadian magmatism and temporal variation in organic matter 106 content during Marcellus Shale deposition. 


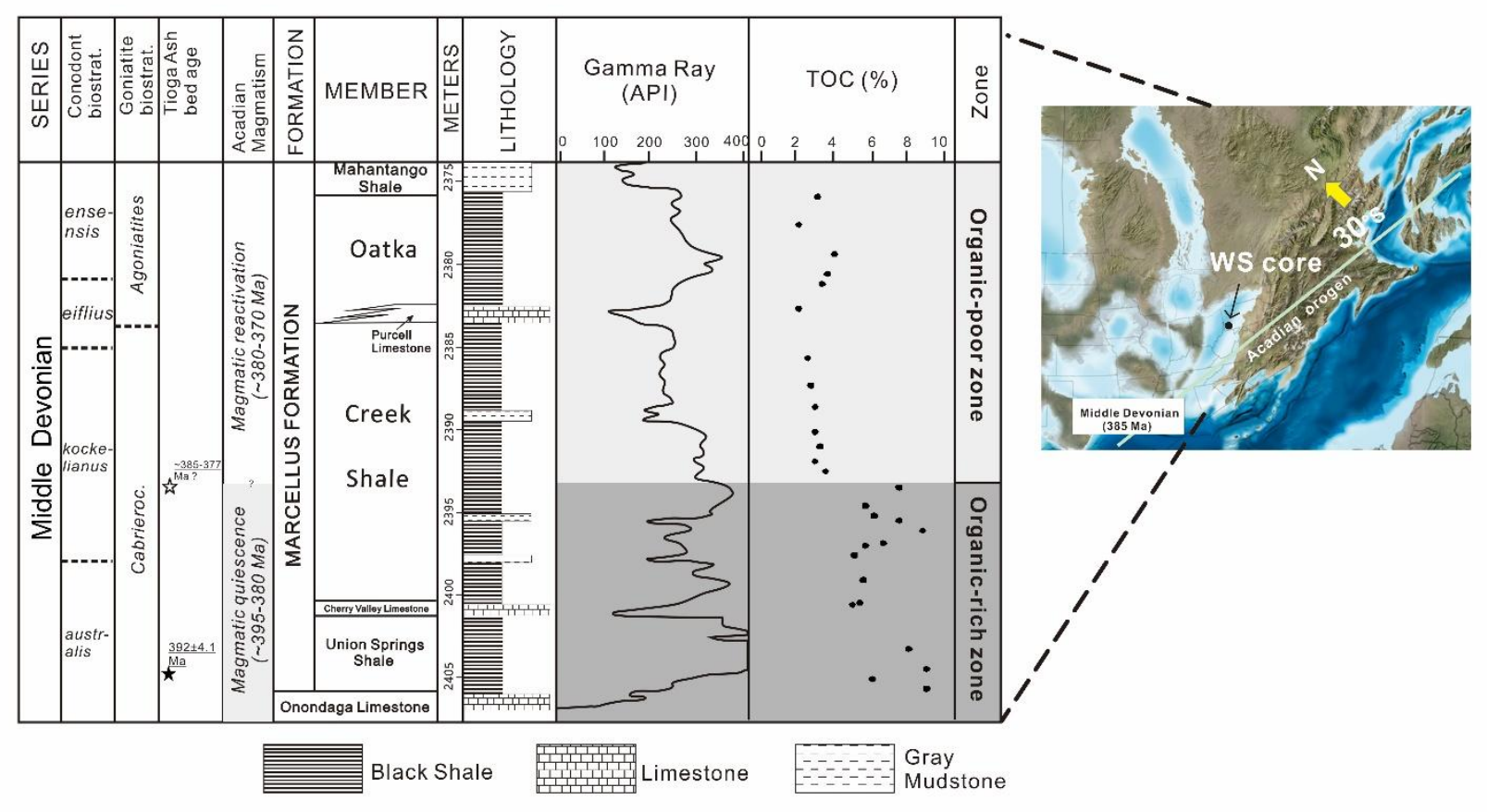

109 Figure 2: Location and stratigraphic column of the studied Marcellus Shale core plotted with

110 biostratigraphic and ash-bed age constraints (Bergström, 1970; Hayward, 2012; Parrish, 2013).

111 Filled star: depositional age from dating of volcanic ash layers; unfilled star: depositional age

112 estimated using sediment accumulation rates (Hayward, 2012; Parrish, 2013). The timing of the

113 Acadian magmatism is from Murphy et al. (1999). The Middle Devonian paleogeography map

114 was modified after Blakey (2013).

\section{Sampling and Analytical Methods}


The Marcellus Shale is the basal unit of the Hamilton Group of the Appalachian basin,

119

120

121

122

123

124

125

126

127

128

129

130

131

132

133

134

135

136

137

138

139

underlain by the Onondaga Limestone and overlain by the Mahantango Shale (i.e., Ettensohn, 1985). The Marcellus Shale well core used in this study is the Whipkey State \#1 (WS) and was cored in September 2008 by Eastern American Energy Corporation, API number 3705924715. The surface location of this well is in Greene County (Latitude: 39.92, Longitude: -80.00), southwestern Pennsylvania (Fig. 2). The studied Marcellus interval is divided into two zones based on total organic carbon (TOC) content: a $12 \mathrm{~m}$ thick organic-rich (OR) zone (2404 to $2392 \mathrm{~m}$ core depth) and a $\sim 18 \mathrm{~m}$ thick organic-poor (OP) zone (2392 to $2374 \mathrm{~m}$ core depth). The OR zone is characterized by high TOC content (range from 5 to $9 \mathrm{wt} . \%$, average $=7 \mathrm{wt} . \%$ ) and high gamma-ray log response (average $=\sim 300 \mathrm{API}$ ). In contrast, the OP zone has lower TOC content (range from 2 to $4 \mathrm{wt} . \%$, average $=3 \mathrm{wt} . \%$ ) and lower gamma-ray log response (average $=$ 200 API) (Fig. 2). The OR zone consists of the entire Union Spring Shale Member and lower part of the Oatka Creek Shale Member while the OP zone corresponds to upper part of the Oatka Creek Shale Member (Fig. 2). Both the OR and OP zones are dominated by black shale interbedded with gray mudstone, siltstone, and limestone. The Purcell Limestone and Cherry Valley Limestone occur as distinct interbeds within the OP and OR zones, respectively.

A total of 26 rock samples were collected from the Marcellus interval of the WS core for elemental analyses, with an average sampling interval of $\sim 1 \mathrm{~m}$. Samples from the carbonate-rich intervals were not included as they are primarily authigenic and hence would not reflect REE signals of the source area. Samples were collected from the inner part of the core using chisel and hammer. Thin rock chips were further ground to homogenous powders prior to geochemical analyses. Thirteen of the samples are chosen from the OR zone and the rest are from the OP zone 
140 (Fig. 2). Notable sampling gaps beneath the Purcell and Cherry Valley limestone beds are due to 141 lack of core material associated with low core recovery.

142 2.2. Analytical methods

Major, trace and rare earth elemental concentrations were measured at Activation

144 Laboratory in Canada using sodium peroxide fusion method. For each sample, $200 \mathrm{mesh}, 0.5 \mathrm{~g}$

145 powders were oxidized and fused with sodium peroxide $\left(\mathrm{Na}_{2} \mathrm{O}_{2}\right)$. The fused samples are diluted

146 and analyzed using a PerkinElmer SCIEX ELAN 6000 ICP/MS. Controls and standards fused

147 with samples are run every 22 samples. Fused duplicates are run every 10 samples. International

148 standards of GXR-4 and OREAS 101a were used to monitor analytical quality. The precision of

149 measurements is better than $1 \%$ for all major elements. For trace and rare earth elements, the

150 accuracy and precision were estimated to be better than $10 \%$. Based on the atomic number, light

151 rare earth elements (LREE) in this study includes $\mathrm{La}, \mathrm{Pr}, \mathrm{Nd}, \mathrm{Sm}$, and the heavy rare earth

152 elements (HREE) include Gd, Tb, Dy, Ho, Er, Tm, and Yb. All measured elemental abundances

153 are corrected for dilution effect caused by varying total organic carbon (TOC) contents, using an

154 ash basis equation:

Ash content $(\%)=-1.0834[\mathrm{TOC}(\%)]+94.981$

156 This equation was developed to estimate the correlation between carbon content and ash content

157 from a study of bulk, trace, and rare earth elements in 300 coal and shale samples (NETL

158 unpublished data source: https://edx.netl.doe.gov/ree/?page_id=1602).

159 3. Results 
161 Table S1), with the values, normalized to the Upper Continental Crust (UCC) standard (Fig. 3)

162 (McLennan, 2001). Samples from the OP zone are characterized by very similar UCC-

163 normalized major- and trace elemental patterns, whereas samples in the OR zone display much

164 variable concentration patterns (Fig. 3). Generally, samples from the OR Zone are relatively

165 depleted in $\mathrm{Al}, \mathrm{K}, \mathrm{Fe}, \mathrm{Mg}, \mathrm{Ti}, \mathrm{Rb}, \mathrm{Cs}$, and $\mathrm{Th}$ but enriched in $\mathrm{Ca}$.

166

\begin{tabular}{|c|c|c|c|c|c|c|c|c|c|c|c|}
\hline Sample & $\begin{array}{c}\mathrm{Si} \\
\mathrm{wt} \%\end{array}$ & $\begin{array}{c}\text { Al } \\
w t \%\end{array}$ & $\begin{array}{c}K \\
w t \%\end{array}$ & $\begin{array}{c}\mathrm{Fe} \\
\mathrm{wt} \%\end{array}$ & $\begin{array}{c}\mathrm{Mg} \\
\mathrm{wt} \%\end{array}$ & $\begin{array}{c}\mathrm{Ca} \\
\mathrm{wt} \%\end{array}$ & $\begin{array}{c}\mathrm{Ti} \\
\mathrm{wt} \%\end{array}$ & $\begin{array}{c}\text { Rb } \\
\text { ppm }\end{array}$ & $\begin{array}{c}\text { Cs } \\
\text { ppm }\end{array}$ & $\begin{array}{c}\text { Ta } \\
\text { ppm }\end{array}$ & $\begin{array}{c}\text { Th } \\
\text { ppm }\end{array}$ \\
\hline WS-7795 & 26.5 & 11.9 & 4.6 & 6.8 & 1.0 & 0.4 & 0.5 & 247.5 & 18.0 & 1.0 & 14.5 \\
\hline WS-7801 & 26.5 & 10.2 & 3.9 & 5.0 & 1.0 & 1.2 & 0.4 & 204.5 & 13.8 & 0.9 & 11.8 \\
\hline WS-7807 & 23.6 & 9.5 & 3.7 & 9.3 & 1.0 & 4.6 & 0.4 & 201.6 & 14.0 & 0.7 & 10.1 \\
\hline WS-7811 & 26.8 & 10.4 & 3.9 & 6.8 & 1.0 & 2.7 & 0.4 & 217.1 & 15.4 & 0.7 & 11.8 \\
\hline WS-7813 & 27.5 & 11.1 & 4.3 & 6.5 & 1.0 & 0.6 & 0.5 & 240.4 & 17.3 & 0.8 & 12.5 \\
\hline WS-7818 & 28.4 & 11.3 & 4.4 & 6.2 & 1.0 & 0.5 & 0.5 & 247.5 & 17.8 & 1.0 & 14.0 \\
\hline WS-7828 & 30.0 & 10.2 & 3.9 & 4.2 & 1.0 & 0.8 & 0.5 & 207.8 & 13.2 & 1.1 & 12.6 \\
\hline WS-7833 & 30.1 & 11.2 & 4.3 & 4.4 & 1.3 & 1.6 & 0.5 & 235.4 & 22.2 & 0.9 & 11.9 \\
\hline WS-7838 & 28.5 & 10.7 & 4.1 & 4.8 & 1.0 & 0.5 & 0.5 & 212.1 & 14.6 & 1.1 & 11.1 \\
\hline WS-7843 & 30.1 & 10.0 & 3.9 & 4.4 & 1.0 & 0.8 & 0.4 & 224.0 & 15.3 & 0.9 & 12.1 \\
\hline WS-7846 & 19.5 & 8.4 & 3.5 & 4.2 & 0.9 & 1.7 & 0.4 & 174.6 & 12.1 & 0.5 & 10.6 \\
\hline WS-7849 & 31.4 & 8.8 & 3.5 & 4.8 & 0.9 & 1.3 & 0.4 & 178.4 & 12.0 & 0.7 & 8.8 \\
\hline WS-7851 & 31.4 & 8.6 & 3.5 & 4.2 & 0.9 & 1.6 & 0.4 & 184.0 & 12.8 & 0.8 & 9.6 \\
\hline WS-7854 & 31.9 & 8.5 & 3.5 & 4.7 & 0.8 & 1.0 & 0.4 & 163.5 & 11.3 & 0.8 & 9.8 \\
\hline WS-7858 & 29.8 & 8.5 & 3.5 & 5.0 & 0.9 & 1.5 & 0.4 & 187.8 & 14.5 & 0.7 & 10.6 \\
\hline WS-7860 & 25.3 & 7.5 & 2.9 & 9.7 & 0.9 & 1.6 & 0.4 & 156.2 & 12.0 & 0.5 & 8.4 \\
\hline WS-7863 & 29.8 & 6.7 & 2.7 & 3.4 & 1.0 & 5.0 & 0.3 & 141.6 & 10.6 & 0.5 & 8.9 \\
\hline WS-7865 & 27.9 & 5.4 & 2.2 & 2.4 & 0.9 & 10.0 & 0.3 & 113.9 & 8.3 & 0.6 & 9.8 \\
\hline WS-7866 & 25.5 & 8.3 & 3.4 & 3.9 & 1.0 & 1.6 & 0.4 & 157.5 & 11.7 & 0.9 & 11.8 \\
\hline WS-7873 & 31.6 & 8.0 & 3.3 & 4.7 & 0.7 & 1.6 & 0.4 & 162.9 & 12.0 & 0.7 & 9.0 \\
\hline WS-7877 & 30.4 & 7.5 & 3.1 & 4.4 & 0.8 & 2.5 & 0.4 & 172.6 & 12.6 & 0.7 & 9.6 \\
\hline WS-7878 & 28.2 & 7.1 & 3.0 & 3.5 & 0.6 & 5.3 & 0.4 & 143.9 & 10.6 & 0.7 & 9.4 \\
\hline WS-7887 & 15.2 & 1.4 & 0.6 & 1.9 & 0.4 & 11.4 & 0.1 & 25.1 & 1.9 & $<0.2$ & 1.7 \\
\hline WS-7891 & 28.6 & 4.2 & 1.8 & 6.6 & 1.0 & 3.9 & 0.2 & 79.7 & 5.7 & 0.5 & 6.2 \\
\hline WS-7893 & 35.0 & 3.6 & 1.6 & 3.3 & 0.5 & 1.2 & 0.2 & 76.4 & 5.1 & 0.2 & 4.4 \\
\hline WS-7895 & 22.4 & 7.8 & 3.1 & 2.8 & 1.5 & 6.0 & 0.4 & 77.9 & 5.2 & $<0.2$ & 2.8 \\
\hline
\end{tabular}

167 Table 1: Selected major and trace element concentrations in the WS core. Trace element data has 
been corrected per sample on an ash basis.

169

170

171

172

173

174

175

176

177

178

179

180

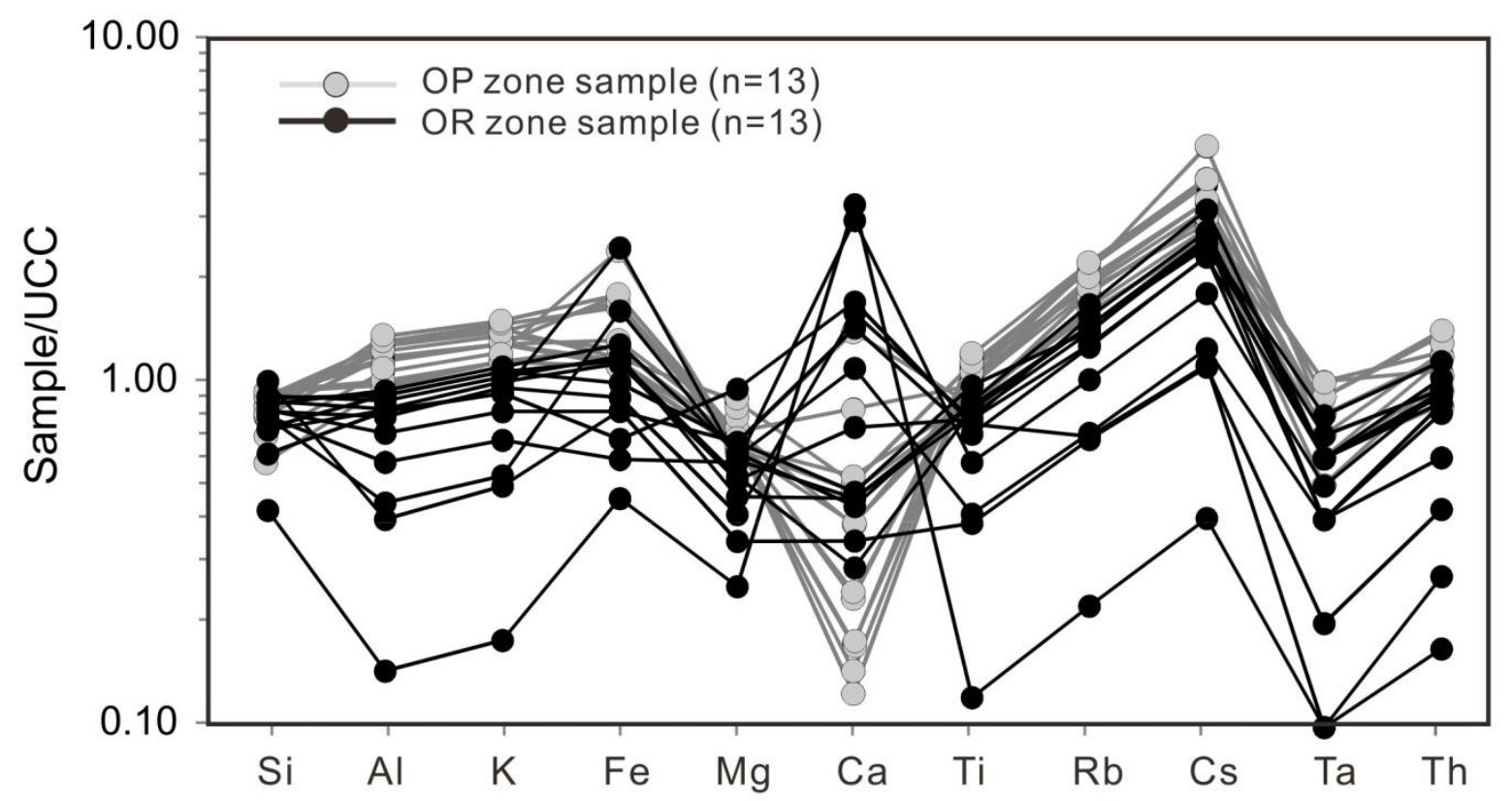

Figure 3: Selected major and trace elements normalized to UCC (McLennan, 2001) for the WS core samples.

Total abundance of ash basis- REE values varies from 69.3 to $235.6 \mathrm{ppm}$ in the studied samples (Table 2, Fig. 4). Raw data of REEs are shown in Table S2. The OP zone contains a higher abundance of REE than that of the OR zone, with values, ranging from 183 to $235.6 \mathrm{ppm}$ $($ average $=199 \mathrm{ppm})$ for the OP zone, and 69.3 to $220 \mathrm{ppm}($ average $=165.8 \mathrm{ppm})$ for the OR zone. REE data are normalized to Post-Archean Australian Shale (PAAS) standard (Fig. 4) (McLennan, 1989). Samples in the OP zone are characterized by remarkably similar patterns of LREE and moderately variable HREE content (Fig. 4). In comparison, both LREE and HREE patterns are highly variable in samples from the OR zone (Fig. 4). 


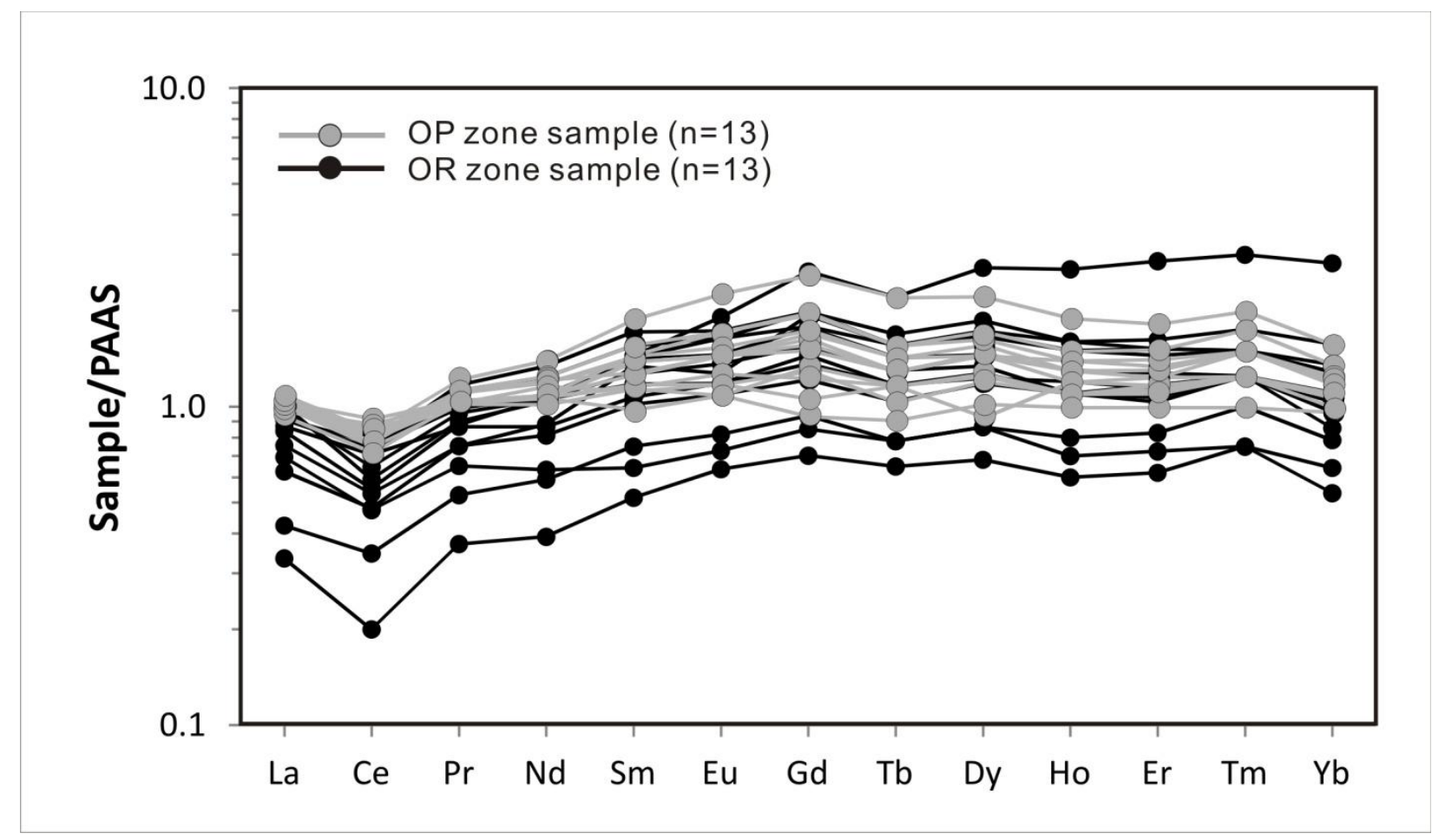

181

182 183

184 185 186 187 188 189 190 191 192 193 194 195 196 197 198

85

Figure 4: PAAS-normalized REE distribution patterns of the WS core samples. The REE values of PAAS are from McLennan et al. (1980a). 


\begin{tabular}{|c|c|c|c|c|c|c|c|c|c|c|c|c|c|c|}
\hline Sample & La & $\mathrm{Ce}$ & $\mathrm{Pr}$ & Nd & Sm & Eu & Gd & $\mathrm{Tb}$ & Dy & Ho & Er & $\mathrm{Tm}$ & Yb & ¿REE \\
\hline WS-7795 & 41.3 & 74.7 & 10.0 & 40.7 & 6.9 & 1.4 & 5.5 & 1.0 & 4.5 & 1.3 & 3.7 & 0.5 & 3.3 & 194.7 \\
\hline WS-7801 & 40.2 & 76.1 & 10.1 & 36.8 & 8.4 & 1.7 & 8.6 & 1.2 & 6.9 & 1.3 & 3.9 & 0.5 & 3.2 & 199.0 \\
\hline WS-7807 & 45.5 & 74.3 & 12.0 & 49.6 & 11.7 & 2.8 & 13.4 & 1.9 & 10.8 & 2.1 & 5.8 & 0.9 & 4.8 & 235.6 \\
\hline WS-7811 & 42.2 & 68.1 & 10.9 & 42.0 & 8.9 & 1.9 & 9.0 & 1.2 & 7.6 & 1.4 & 4.2 & 0.7 & 3.7 & 201.7 \\
\hline WS-7813 & 42.4 & 69.4 & 10.2 & 37.7 & 7.1 & 1.5 & 6.3 & 1.0 & 6.0 & 1.2 & 3.6 & 0.5 & 3.3 & 190.2 \\
\hline WS-7818 & 43.6 & 69.8 & 9.9 & 36.8 & 5.9 & 1.3 & 4.7 & 0.8 & 4.8 & 1.1 & 3.1 & 0.4 & 2.9 & 185.2 \\
\hline WS-7828 & 42.6 & 79.8 & 10.2 & 37.3 & 7.1 & 1.4 & 6.6 & 0.9 & 5.7 & 1.2 & 3.5 & 0.5 & 3.0 & 199.9 \\
\hline WS-7833 & 42.5 & 71.4 & 11.0 & 41.9 & 8.5 & 1.7 & 8.4 & 1.1 & 7.1 & 1.4 & 3.9 & 0.7 & 3.6 & 203.0 \\
\hline WS-7838 & 41.2 & 65.4 & 9.9 & 35.6 & 7.0 & 1.3 & 6.9 & 1.0 & 6.1 & 1.2 & 3.7 & 0.5 & 3.4 & 183.0 \\
\hline WS-7843 & 44.7 & 70.9 & 10.8 & 42.4 & 7.8 & 1.7 & 7.7 & 1.1 & 7.0 & 1.5 & 4.2 & 0.7 & 3.8 & 204.4 \\
\hline WS-7846 & 40.6 & 73.3 & 10.2 & 38.2 & 8.9 & 2.1 & 10.0 & 1.3 & 7.9 & 1.5 & 4.5 & 0.7 & 3.7 & 202.9 \\
\hline WS-7849 & 38.7 & 62.6 & 10.1 & 38.1 & 7.7 & 1.7 & 8.0 & 1.1 & 7.0 & 1.4 & 4.1 & 0.7 & 3.6 & 184.9 \\
\hline WS-7851 & 42.1 & 68.0 & 11.1 & 43.9 & 9.6 & 2.1 & 10.2 & 1.3 & 8.3 & 1.6 & 4.8 & 0.8 & 4.2 & 208.0 \\
\hline WS-7854 & 38.0 & 65.2 & 8.9 & 31.9 & 6.9 & 1.5 & 7.4 & 1.0 & 6.2 & 1.4 & 3.8 & 0.6 & 3.3 & 176.0 \\
\hline WS-7858 & 42.7 & 68.7 & 11.2 & 44.6 & 9.8 & 2.0 & 9.4 & 1.3 & 8.2 & 1.7 & 4.7 & 0.7 & 4.0 & 209.3 \\
\hline WS-7860 & 41.5 & 58.6 & 9.6 & 38.2 & 7.5 & 1.5 & 7.7 & 1.0 & 6.3 & 1.2 & 3.4 & 0.6 & 2.7 & 179.9 \\
\hline WS-7863 & 37.3 & 51.7 & 9.1 & 39.9 & 8.3 & 1.8 & 8.5 & 1.2 & 6.9 & 1.3 & 4.0 & 0.6 & 3.2 & 173.8 \\
\hline WS-7865 & 43.5 & 68.3 & 11.8 & 48.8 & 10.9 & 2.2 & 10.6 & 1.5 & 9.3 & 1.8 & 5.4 & 0.8 & 5.0 & 220.0 \\
\hline WS-7866 & 38.9 & 66.6 & 9.9 & 39.3 & 8.9 & 1.8 & 9.3 & 1.2 & 7.2 & 1.5 & 4.2 & 0.6 & 3.5 & 192.8 \\
\hline WS-7873 & 29.7 & 42.6 & 6.5 & 22.8 & 4.0 & 0.9 & 4.5 & 0.7 & 4.3 & 0.9 & 2.7 & 0.4 & 2.5 & 122.4 \\
\hline WS-7877 & 32.2 & 47.8 & 7.5 & 29.1 & 6.4 & 1.3 & 6.4 & 0.9 & 5.8 & 1.2 & 3.5 & 0.6 & 3.2 & 146.0 \\
\hline WS-7878 & 38.8 & 68.7 & 9.8 & 38.3 & 8.9 & 2.0 & 10.4 & 1.3 & 8.4 & 1.7 & 4.9 & 0.7 & 4.2 & 198.1 \\
\hline WS-7887 & 44.6 & 54.8 & 9.3 & 38.6 & 9.4 & 2.4 & 14.5 & 2.0 & 13.9 & 3.1 & 9.6 & 1.4 & 9.2 & 212.7 \\
\hline WS-7891 & 27.9 & 45.1 & 7.9 & 33.1 & 8.8 & 1.6 & 10.7 & 1.4 & 8.9 & 1.9 & 5.2 & 0.7 & 4.2 & 157.3 \\
\hline WS-7893 & 18.2 & 31.3 & 5.3 & 21.4 & 4.7 & 1.0 & 5.0 & 0.7 & 4.3 & 0.8 & 2.4 & 0.3 & 2.0 & 97.4 \\
\hline WS-7895 & 14.9 & 18.8 & 3.9 & 14.7 & 3.4 & 0.8 & 3.9 & 0.6 & 3.5 & 0.7 & 2.1 & 0.4 & 1.8 & 69.3 \\
\hline
\end{tabular}

199

200 Table 2: REE contents of the Marcellus Shale for the WS core (ppm). Data has been corrected

201 per sample on an ash basis.

202

203

\section{Discussion}

\subsection{Sediment provenance of the Marcellus Shale}

The chondrite-normalized LREE distribution pattern has been widely used as a sensitive indicator for determining the sediment source of the sedimentary rocks (McLennan et al., 1980b;

Paikaray et al., 2008). Felsic sources are represented by North American Shale Composite 
(NASC) and mafic sources are represented by Mid-Ocean Ridge Basalt (MORB) (Fig. 5)

(McLennan et al., 1980a; Totten and Hanan, 1998). The samples from NASC and MORB have studied interval, the samples from the OP zone display very small ranges of LREE values that

211 closely overlap with the NASC standard, which indicates that the sediments were mostly derived

212 from sources that have similar REE compositions as the NASC. Samples from the OR zone are 213 characterized by variable LREE patterns (Fig. 5). Furthermore, a few samples are distributed in 214 the middle of NASC and MORB, indicating a relatively high proportion of mafic igneous rocks 215 compared to those in the OP zone. Overall, the REE patterns suggest an increasing contribution 216 of felsic sources during the deposition of the Marcellus Shale in our study unit.

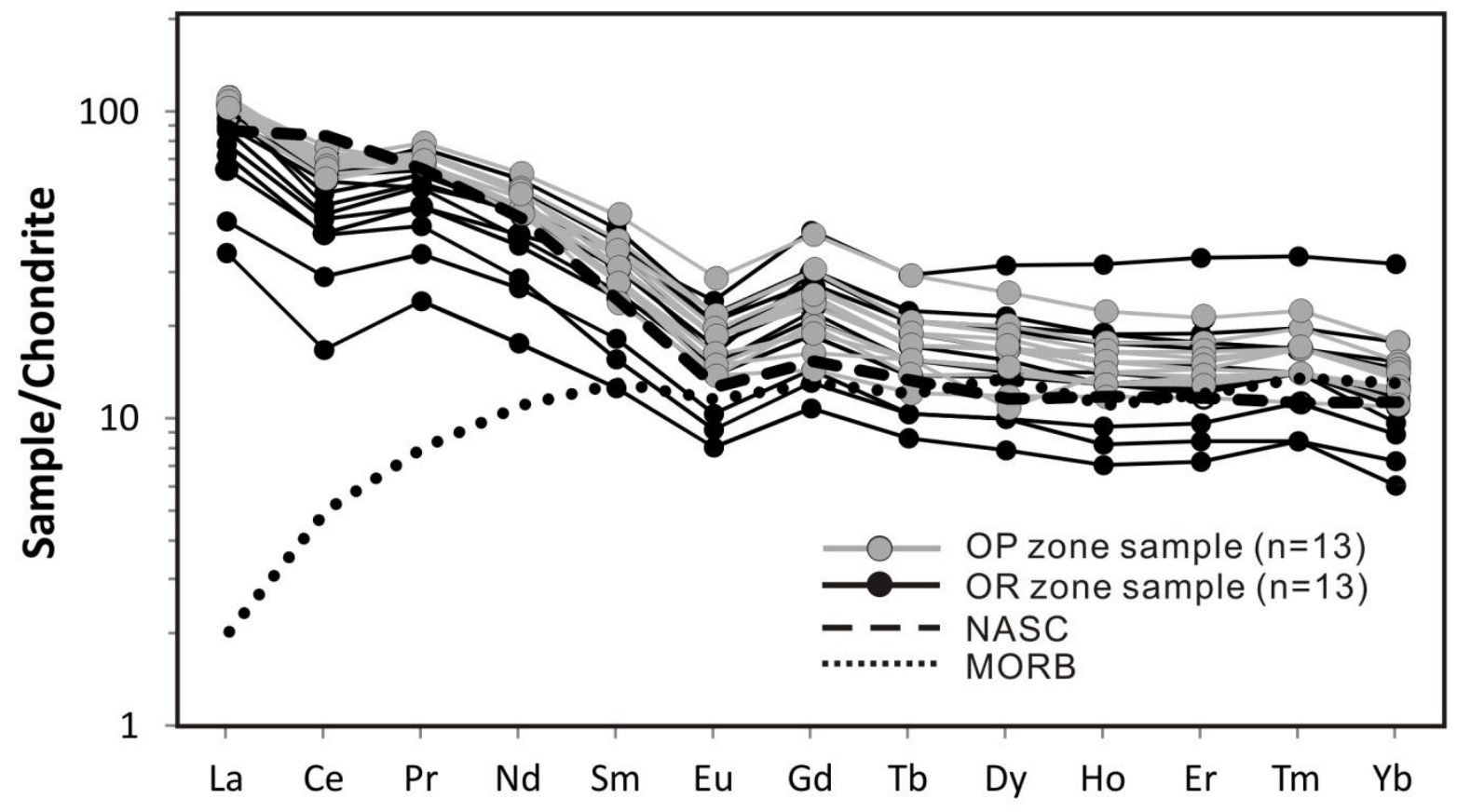

218 Figure 5: Chondrite-normalized REE distribution patterns of the WS core samples. The REE

219 values of chondrite are from McLennan et al. (1980). 
As previously discussed, the hypothesis that deposition of organic-rich and organic poor

222 zones in the Marcellus Shale might be related to tectonic activities of the Acadian Orogeny can

223 be tested by temporal and chemostratigraphic correlation of Acadian orogenic and magmatic

224 events with geochemical signals recorded by the shale strata.

\subsubsection{Temporal correlation}

Previously, the depositional age of the Marcellus Shale was only loosely constrained at

227 Middle Devonian (Eifelian-Givetian) based on conodont biostratigraphy (e.g., Bergström, 1970)

228 (Fig. 2). However, with the recent dating of the Tioga ash layers in the basal part of the

229 Marcellus Shale and development of high-resolution U-Pb zircon dating techniques, depositional 230 ages of Marcellus strata have been more accurately determined (Hayward, 2012; Parrish, 2013). 231 Dating of zircon grains from the Tioga ash layers shows that onset of the Marcellus deposition 232 likely occurred diachronously in the Acadian foreland basin with estimated depositional age of 233 the basal Marcellus spanning an interval of $394 \pm 5$ Ma to $389 \pm 3$ Ma (Parrish, 2013). In the 234 studied core (i.e., St. Whipkey \#1) in southeastern PA, the dating of two ash layers suggests 235 deposition of the Marcellus Shale likely started at between $389 \pm 5.8 \mathrm{Ma}$ and $395 \pm 5.7 \mathrm{Ma}$ 236 (average $=392 \pm 4.1 \mathrm{Ma})($ Parrish, 2013). The estimated depositional ages from our study well is 237 consistent with the ash bed ages obtained from the adjacent wells (i.e., EQT 511391, Coldstream 238 \#1, Winner 4-8, Fortuna FEI Thomas; see Parrish, 2013 for well locations), which shows an 239 average age of basal Marcellus at $392.8 \pm 1.6 \mathrm{Ma}$ (range $=\sim 397-\sim 387 \mathrm{Ma}$ ). It is worth noting 240 that currently, radiometric ages are only available from the basal part of Marcellus strata where 241 volcanic ash layers were discovered, and depositional ages for the middle and upper Marcellus 
242 can only be derived using estimated shale accumulation rates (Hayward, 2012). The average

243 sedimentation rates calculated in this study were based on dates obtained from ash layers

244 reported from all the wells near the study area. For example, the Coldstream \#1 well in Clearfield,

245 Pennsylvania contains two ash beds (i.e., ash bed \#1 Cold2, 7157.2', $391.3 \pm 4.8 \mathrm{Ma}$; and ash

246 bed \#2 Cold4, 7162.4', $393.4 \pm 5.5 \mathrm{Ma}$ ), which are separated by 5.2 feet of Marcellus Shale

247 interval with an average of 2.1 Ma age difference. Thus, the compacted sedimentation rate for

248 the well was calculated at $\sim 2.5 \mathrm{ft} / \mathrm{m} . \mathrm{y}$. (Table. 3). Based on the sedimentation rates from all the

249 adjacent wells, we estimate the average sedimentation rates for the Marcellus shale in the study

250 area to be $\sim 4.3 \mathrm{ft} / \mathrm{m}$.y. However, it is worth noting that current precision of the SIMS U-Pb

251 zircon dating method is at between plus and minus 2 to $5 \mathrm{Ma}$ (Deloule et al., 2002). Therefore,

252 uncertainties associated with the zircon dating technique make it difficult to resolve short

253 timescale variations. In addition, there is a paucity of ash layers in the upper Marcellus hence

254 most U-Pb ages are from volcanic ash layers (Tioga ash beds) found near the base of the

255 Marcellus Shale. Therefore, the estimated average sedimentation rates most likely represent the

256 depositional conditions during the deposition of the basal part of the Marcellus Shale. This part

257 of the Marcellus Shale is highly organic-rich with average TOC values close to $8.5 \%$ (Fig. 2) and

258 deposition of such high TOC units is usually linked to the extremely low clastic influx. Further,

259 the low concentrations of trace metals (Fig. 6) and $\mathrm{Al}$ and Ti contents (Fig. 8) also support that

260 the clastic influx was extremely low during the beginning of the Marcellus Shale deposition. As

261 a result, the low sedimentation rates (i.e., $4.3 \mathrm{ft} / \mathrm{m} . \mathrm{y}$.) were expected in our study area.

In the WS core, the base of the Marcellus Shale has an average age at $392 \pm 4.1 \mathrm{Ma}$

263 (Parrish, 2013). Using the estimated average shale compacted sedimentation rates (i.e., 4.3

$264 \mathrm{ft} / \mathrm{m} . \mathrm{y}$.$) , the age of top of the OR zone is likely at between 385 \mathrm{Ma}$ and $377 \mathrm{Ma}$ if uncertainty in 
265 the ash ages is considered. Temporal correlation of the Marcellus Shale deposition and the

266 Acadian magmatism (Fig. 1), reveals that deposition of the OR zone sediments was generally

267 coincident with the magmatic quiescent period of the Acadian orogeny which lasted from 395

268 to $\sim 380 \mathrm{Ma}$ (Murphy et al., 1999). Tectonic synthesis show that the magmatic quiescence stage

269 which lasted from $\sim 395$ to $\sim 380$ Ma was accompanied by extensive crustal shortening (>600 km),

270 and orogenic activities related to convergence between the North America plate and Avalon

271 terrane (Murphy et al., 1999). Coupling of the sub-ducted and overlying plates led to significant

272 thickening of continental crust and inhibited the penetration of mantle plume into the continental

273 crust, which accounts for the lack of magmatism in the Acadian mountain during this time

274 (Murphy et al., 1999). It has been suggested that the initial coupling of the subducting and

275 overriding plates led to rapid uplift of the Acadian mountain and by inference, rapid subsidence

276 and deepening of the adjacent Acadian foreland basin (Murphy et al., 1999). This suggests that

277 the rise of the Acadian orogen was coincident with the initiation of organic-rich shale deposition

278 of the Marcellus Formation (i.e., the OR zone).

The subsequent deposition of the overlying OP zone sediments most likely initiated at

$280 \sim 382-374 \mathrm{Ma}$, which coincides with the period of magmatic reactivation in Acadian Orogeny

281 lasting from 380-370 Ma (Murphy et al., 1999). During this time period, there was a progressive

282 thermal erosion of continental crust by the mantle plume, thus, the crust was exposed to hot

283 asthenosphere (Murphy et al., 1999). In addition, reactivation of Acadian magmatism was

284 accompanied by the intrusion of extensive granitoid batholiths and continued convergence and

285 deformation along the North America plate margin. This led to extensive cratonward migration

286 of the Acadian organic belt, providing voluminous felsic sediments into the adjacent Acadian

287 foreland basin (Murphy et al., 1999). 


\begin{tabular}{|c|c|c|c|c|c|}
\hline \multicolumn{6}{|c|}{ Tioga Ash Ages and Sedimentation Rates } \\
\hline $\begin{array}{l}\text { Well Name } \\
\text { County, State }\end{array}$ & $\begin{array}{l}\text { Sample } \\
\text { ID }\end{array}$ & $\begin{array}{c}\text { Ash \# } \\
\text { (depth in ft.) }\end{array}$ & $\begin{array}{c}\text { Avg. } \\
{ }^{238} \mathrm{U} /{ }^{206} \mathrm{~Pb} \\
\text { Age (Ma) }\end{array}$ & $\begin{array}{c}\text { Measured } \\
\text { interval (ft.) }\end{array}$ & $\begin{array}{l}\text { Compacted } \\
\text { sedimentation } \\
\text { rate }(\mathrm{ft} / \mathrm{my})\end{array}$ \\
\hline \multirow{2}{*}{ EQT 511391} & EQT1 & $1(7114.9)$ & $394.2 \pm 5.4$ & \multirow{2}{*}{ 7117.05-7114.9 } & \multirow{2}{*}{1.2} \\
\hline & EQT2 & $2(7117.05)$ & $396.7 \pm 5.0$ & & \\
\hline \multirow{2}{*}{ Armstrong \#1 } & Arm1 & $1(7755.27)$ & $388.1 \pm 5.1$ & \multirow{2}{*}{ 7771.9-7755.27 } & \multirow{2}{*}{2.5} \\
\hline & Arm4 & $4(7771.9)$ & $390.6 \pm 2.7$ & & \\
\hline \multirow{2}{*}{ St. Whipkey \#1 } & Whip2 & 2 (7893.6) & $395.1 \pm 5.7$ & & \\
\hline & Whip4 & $4(7897.5)$ & $388.7 \pm 5.8$ & & \\
\hline \multirow{3}{*}{ Coldstream \#1 } & Cold2 & $2(7157.2)$ & $391.3 \pm 4.8$ & $7162.4-7157.2$ & 2.5 \\
\hline & Cold4 & $4(7162.4)$ & $393.4 \pm 5.5$ & $7163.5-7162.4$ & 0.35 \\
\hline & Cold5 & $5(7163.5)$ & $396.5 \pm 5.6$ & $7163.5-7157.2$ & 1.2 \\
\hline \multirow{3}{*}{ Winner 4-8 } & Win23 & $1(8023.5)$ & $387.4 \pm 7.8$ & $8035.4-8023.5$ & 3.5 \\
\hline & Win35 & $3(8035.4)$ & $390.8 \pm 9.4$ & 8041.5 - 8035.4 & 8.5 \\
\hline & Win41 & $4(8041.5)$ & $391.5 \pm 8.4$ & $8041.5-8023.5$ & 4.5 \\
\hline \multirow{3}{*}{ Tunnelton CV1 } & Tun52 & $1(7852.0)$ & $387.3 \pm 2.5$ & $7862.5-7852.0$ & 14 \\
\hline & Tun62 & $2(7862.5)$ & $388.0 \pm 3.0$ & $7865.7-7862.5$ & 2.3 \\
\hline & Tun65 & $3(7865.7)$ & $389.3 \pm 3.3$ & $7865.7-7852.0$ & 6.5 \\
\hline
\end{tabular}

Table 3: Dated ash samples and calculated sedimentation rates in the study area. All data were obtained by Parrish (2013).

\subsubsection{Chemostratigraphic correlation}

Temporal correlation of Acadian orogeny with organic-rich shale deposition in the Marcellus Formation suggest that onset of Acadian orogeny played a key role in the onset of deposition of the OR zone. Further, as rare earth and trace element ratios of sedimentary rocks reflect geochemical signatures of their sediment source (e.g., Condie, 1991), chemostratigraphic studies can provide further evidence of this linkage. The previous study of magmatic zircons from the Tioga ash beds shows that the rare earth and trace element compositions of zircon grains are consistent with the continental granitoid origin (Hayward, 2012). Here, we plotted LREE and selected trace elements of shale samples that are least affected by weathering and 
diagenetic process (Figs. 6 and 7). Average elemental compositions of bulk crust and upper crust (similar to granodiorite) (Taylor and McLennan, 1995), were also plotted for comparison with the shale composition. The plots show that trace elements (Th, Rb, Cs and Ta) (Fig. 6) and LREE (La, Pr, Nd, and Sm) (Fig. 7) contents of the studied shale interval display an upward increasing trend. The values in the OR zone are relatively low and scattered and similar to that of the bulk crust. In contrast, the LREE and trace element contents in the OP zone are significantly higher and become more stable with values more similar to that of the average composition of the granodiorite. In addition, it is widely accepted that the volatile trace elements (e.g., Rb) and refractory elements (e.g. Th, REE) are significantly enriched in volcanic plumes, their abundance is governed by magmatic degassing of sulfate/halide compounds (Moune et al., 2006). It is clear that there was a compositional shift of sediment source during the course of the Marcellus Shale deposition. The OR zone shale samples were more likely sourced from the old continental crust, the 'non-magmatic signal' preserved in the OR zone can be correlated to the period of magmatic quiescence between $\sim 395$ and $\sim 380$ Ma. In contrast, the OP zone shale samples have more "granodiorite-like" composition, suggesting significant input from new formed igneous sources. Therefore, the "magmatic signal" preserved in the OP zone can be correlated to the magmatic active period that lasted from $\sim 380$ to $\sim 370 \mathrm{Ma}$. Together, the geochemical signature provides further evidence of the linkage between the Acadian tectonics and organic carbon concentration in the Marcellus Shale.

It is worth noting that the LREE contents are highly variable in the OR zone (Fig. 7). These fluctuations may relate to the development of finer-scale depositional cycles/tectophases in the Appalachian Basin. Orogenic events may have caused changes in sediment source, resulting in variable LREE patterns in the sediment record. A recent study (Chen and Sharma, 
323 2016), suggested that the bottom water redox conditions were alternating between suboxic and

324 anoxic during the deposition of OR zone shale. These alternating redox conditions may reflect

325 the finer-scale water-depth changes primarily controlled by Acadian Orogeny. However, it is

326 difficult to assess the existence of these finer-scale tectophases because a large part of the

327 Acadian mountain has been eroded or tectonically overprinted, especially in the central to

328 southern Appalachian basin (Ver Straeten, 2009).

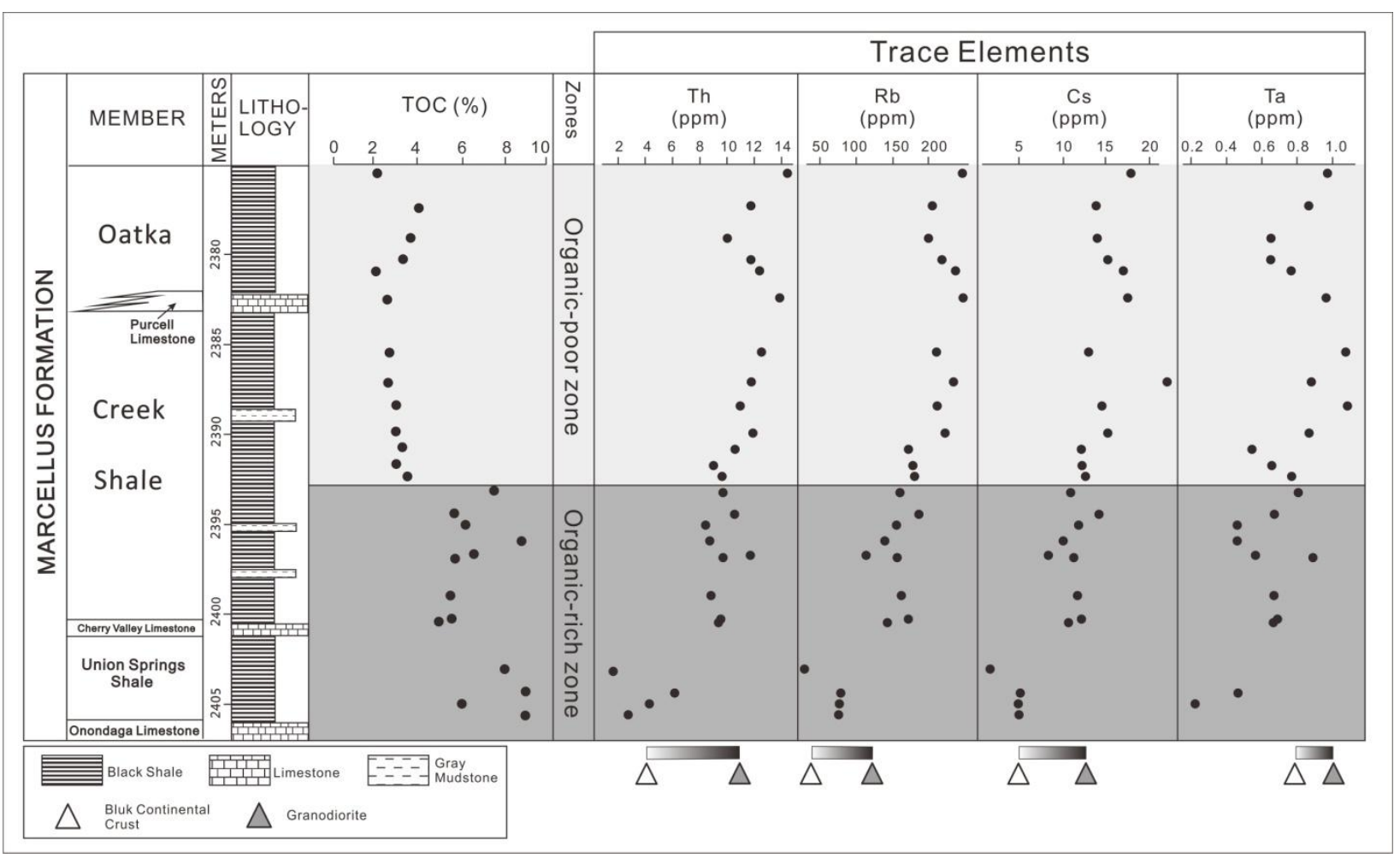

331 Figure 6: Selected trace elements for the WS core. 


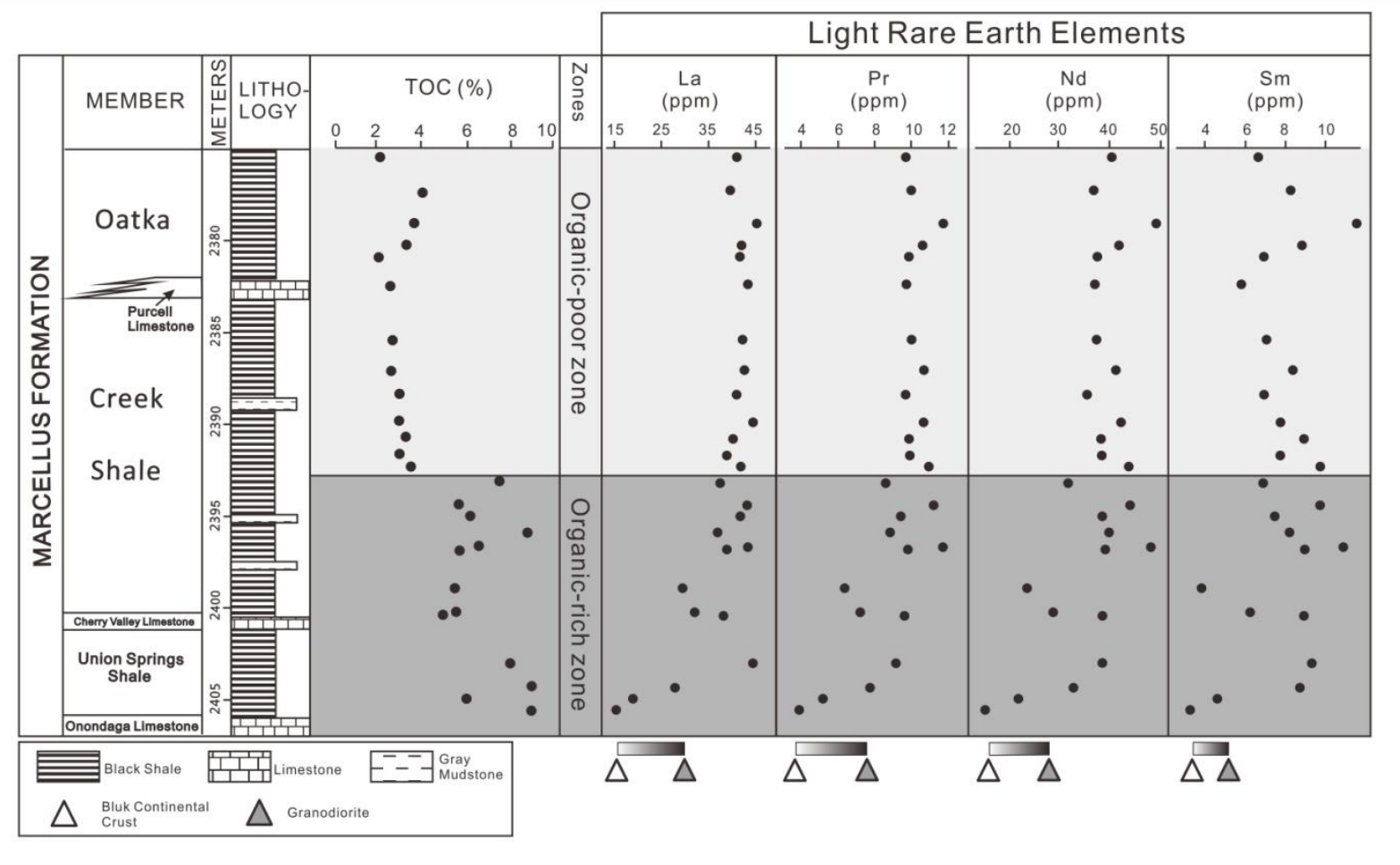

334

Figure 7: LREE profiles for the WS core.

Chemical weathering could potentially alter the LREE and trace element concentrations in the studied shale (Buggle et al., 2011; Clift et al., 2014) and it is necessary to evaluate the variations of chemical weathering intensity at the time of deposition. "Chemical Index of Alteration" (CIA) has been used as a good indicator of chemical weathering for many studies (e.g., Clift et al., 2014; Jian et al., 2013; Nesbitt and Young, 1982; Paikaray et al., 2008). The CIA is calculated from $\mathrm{Al}, \mathrm{Ca}, \mathrm{Na}$ and $\mathrm{K}$ contents (Nesbitt and Young, 1982), however, Na contents are not detectable due to using sodium peroxide $\left(\mathrm{Na}_{2} \mathrm{O}_{2}\right)$ fusion as a pretreatment in our study. In this study, we report the ratios of $\mathrm{K} / \mathrm{Cs}$ and $\mathrm{K} / \mathrm{Rb}$, which show very similar patterns as CIA and can be used as chemical weathering indicators (Cliff et al., 2014). Alkali elements, including $\mathrm{K}$, can be categorized as soluble cations and are relatively mobile in water, while Cs and $\mathrm{Rb}$ are often regarded as immobile elements due to their large ionic radius (e.g., Buggle et al., 
346 2011; Cliff et al., 2014). The ratios K/Cs and K/Rb slightly decrease upward in the WS core (Fig.

347 8), suggesting enhanced chemical weathering during the time of deposition. Consequently, we

348 conclude that the sediments in the OP zone reflect a higher degree of chemical alteration and the

349 original trace element contents of the sediments were probably higher than the present values

350 (Fig. 6). Therefore, the observed compositional differences between the OR and OP zones are

351 likely to be underestimated if we take the effects of potential chemical weathering into

352 consideration.

353 It is also important to note that increased clastic input could also cause higher trace

354 element and LREE concentrations observed in the OP zone. Ti and Al are treated as essentially

355 immobile due to their low solubility of the oxides and hydroxides in low-temperature aqueous

356 solutions (Hayashi et al., 1997; Paikaray et al., 2008), ). They can therefore be considered

357 extremely resistant to weathering (Cliff et al., 2014; Chen et al., 2013; Chen et al., 2015). Ti is

358 highly concentrated in heavy minerals and Al mostly resides in clays and residual feldspars,

359 which are all detrital components (Murray and Leinen, 1996). Therefore, the concentrations of Ti

360 and $\mathrm{Al}$ serve as good proxies for tracing sedimentary transportation processes in our study site.

361 Thus higher concentrations of $\mathrm{Ti}$ and $\mathrm{Al}$ in the OP zone may also suggest a higher supply of

362 siliciclastic materials to the basin compared to the OR zone (Fig. 8). 


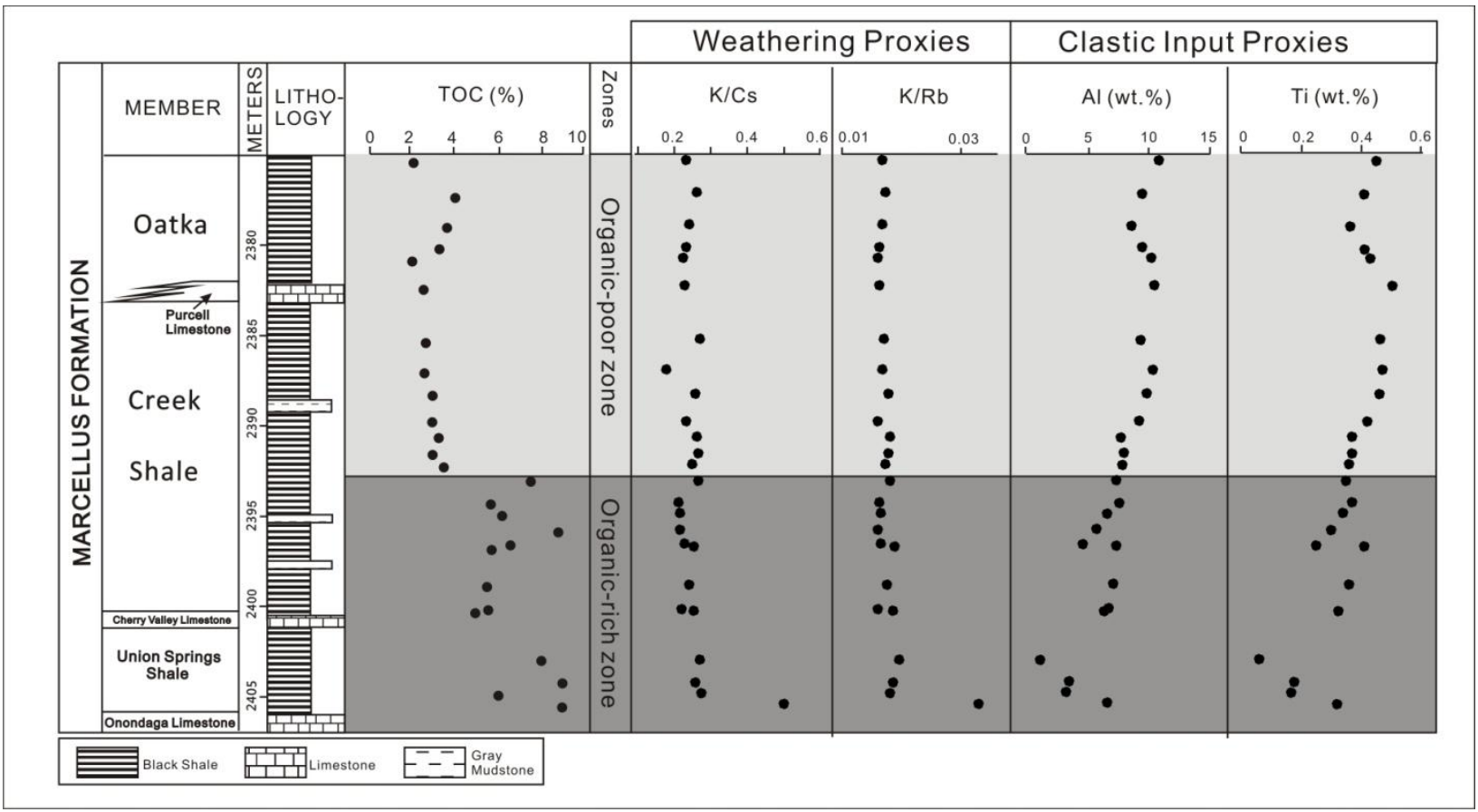

Figure 8: Temporal evolution in proxies linked to chemical weathering and clastic input

366 intensities.

\subsection{Roles of tectonics and erosion on organic matter enrichment in the Marcellus Shale}

During the period of OR zone deposition (ca. 395-380 Ma), mountain building of the

369 Acadian Orogeny was at its highest rate (Murphy et al., 1999; Ver Straeten, 2009, 2010). During

370 this time, the northwestern migration of the deformation front contributed to the development of

371 a flat-slab beneath the Appalachians, causing Lamaride-style orogenic activities (Murphy et al.,

372 1999). Active mountain building of the Acadian orogeny also resulted in increased subsidence in

373 the Acadian foreland basin (Ver Straeten, 2009, 2010). The $\delta^{13} \mathrm{C}_{\mathrm{org}}$ values of samples from the

374 OR zone (ca. $-30.5 \%$ ) suggest organic matter deposited during this period were primarily marine

375 in origin (Chen and Sharma, 2016), reflecting a land-ward shift of environments accompanying a

376 relative deepening of basin water depth (Ettensohn, 1985). During the tectonically active period,

377 uplift of the Acadian Mountain could have acted as a barrier to the moisture-laden east wind, 
causing rain shadow effect on the western side of the Acadian Mountain (Ettensohn and Barron, 1981). The rain shadow effect would have reduced sediment input from rivers into the Appalachian Basin. The lower Ti and Al concentrations in the OR zone (Fig. 8) may reflect the lower influx of land-derived sediments in the basin. Reduced clastic influx combined with deepening of the Acadian foreland basin, would have promoted the accumulation and preservation of organic matter during the tectonically active period (coincident with the magmatic quiescent period), resulting in widespread deposition of OC-rich black shales throughout the basin.

The magmatic quiescent period was abruptly terminated by a magmatic active period marked by the widespread intrusion of granodiorite rocks during the period of ca. $380-370 \mathrm{Ma}$ (Murphy et al., 1999). In the sedimentary record, this is reflected by the high LREE and selected trace element contents preserved in the OP zone. The higher LREE and trace element contents could also possibly suggest higher clastic input. Higher concentrations of Ti and Al in the OP zone also suggest increased influx of siliciclastic materials into the basin during this time period. During periods of tectonic quiescence and magmatic activity, the Acadian Mountain might have slowly lowered due to continued weathering and erosion, resulting in reduced rain shadow effect on the western side of the mountain (Ettensohn and Barron, 1981). The reduced rain shadow effect would have permitted more moisture-laden east wind to cross the mountain, causing more precipitation and increased clastic input into the basin. Furthermore, magmatism within the Acadian orogen may have produced voluminous felsic rocks in the source area which could be a plausible source of sediments during the deposition of the OP zone. The higher clastic input would have probably caused dilution effect resulting in lower organic matter concentration in the OP zone sediments. In the meantime, subsidence would have decreased in the basin's foredeep, 
401 resulting in shallower water depth and suboxic/oxic bottom water condition (Werne et al., 2002;

402 Sageman et al., 2003; Arthur, 2005). Chen and Sharma (2016), suggested that the bottom water

403 redox conditions were dominantly suboxic during the deposition of the OP zone, which is

404 consistent with this interpretation. The higher clastic influx accompanied by faster rates of

405 organic matter oxidation would have decreased the relative organic carbon concentration in

406 sediments and poor preservation of organics, resulting in deposition of organic-poor shale zone.

407 5. Conclusions

408 The tectonics of the Acadian Orogeny has long been linked with organic matter

409 enrichment in the shale deposited in the Appalachian Basin. This study attempts to provide the

410 direct link between the Acadian Orogeny and organic-rich shale deposition. Temporal and

411 geochemical correlation of the Acadian magmatism and magmatic signals preserved in the

412 Marcellus Shale, reveals that the OR zone sediments were mainly formed during the period of

413 tectonically active and magmatic quiescent period of the Acadian Orogeny. In contrast, the

414 higher LREE and selected trace elements in the OP zone sediments indicate deposition during

415 the period of magmatic reactivation of the Acadian Orogeny. In addition, the sediment source

416 indicates a shift from intermediate (mixed of felsic and mafic) to felsic upward throughout the

417 section, also supporting the trend towards higher magmatic activities. Reduced basin subsidence

418 combined with higher sediment influx led to oxic bottom water conditions and organic matter

419 dilution, both of which were not favorable for organic matter preservation in the OP zone of the

420 Marcellus Shale.

421

422 
424 The research was supported by two National Science Foundation grants to Dr. Sharma (NSF 425 EAR-1205596 and NSF DEB-1342732). We would like to thank Drs. Toro, Banks, Carr, 426 Weislogel, and Shang for helpful discussions.

\section{References}

429

430

431

432

433

434

435

436

437

438

439

440

441

442

443

444

445

446

447

448

449

450

451

452

453

454

455

456

457

458

459

460
Arthur, M. A., 2005, Sea-level control on source-rock development: perspectives from the Holocene Black Sea, the mid-Cretaceous Western Interior Basin of North America, and the Late Devonian Appalachian Basin: Society for Sedimentary Geology, Special Publication, v. 82, p. 35-59.

Bergström, S. M., 1970, Conodont biostratigraphy of the Middle and Upper Ordovician of Europe and eastern North America: Geological Society of America Memoirs, v. 127, p. 83-162.

Blakey, R., 2013, North American Paleogeography. http://www2.nau.edu/rcb7/nam. html (accessed 10/24/2016).

Bradley, D. C., 2000, Migration of the Acadian orogen and foreland basin across the northern Appalachians of Maine and adjacent areas, US Department of the Interior, US Geological Survey, Professional Paper, v. 1624, 49 pages.

Buggle, B., Glaser, B., Hambach, U., Gerasimenko, N., and Marković, S., 2011, An evaluation of geochemical weathering indices in loess-paleosol studies: Quaternary International, v. 240 , no. 1 , p. 12-21.

Calvert, S. E., and Pedersen, T. F., 2007, Chapter Fourteen Elemental Proxies for Palaeoclimatic and Palaeoceanographic Variability in Marine Sediments: Interpretation and Application. Developments in Marine Geology, v. 1, p. 567-644.

Chen, H., Yeh, P., Song S., Hsu, S., Yang, T., Wang, Y., Chi, Z., Lee, T., Chen, M., Cheng, C, Zou, J and Chang, Y., 2013, The Ti/Al molar ratio as a new proxy for tracing sediment transportation processes and its application in aeolian events and sea level change in East Asia: Journal of Asian Earth Sciences, v. 73, p. 31-38.

Chen, R., Sharma, S., Bank, T., Soeder, D., and Eastman, H., 2015, Comparison of isotopic and geochemical characteristics of sediments from a gas- and liquids-prone wells in Marcellus Shale from Appalachian Basin, West Virginia: Applied Geochemistry, v. 60, p. $59-71$. 
Chen, R., and Sharma, S., 2016, Role of alternating redox conditions in the formation of organicrich interval in the Middle Devonian Marcellus Shale, Appalachian Basin, USA: Palaeogeography, Palaeoclimatology, Palaeoecology, v. 446, p. 85-97.

Clift, P. D., Wan, S., and Blusztajn, J., 2014, Reconstructing chemical weathering, physical erosion and monsoon intensity since $25 \mathrm{Ma}$ in the northern South China Sea: A review of competing proxies: Earth-Science Reviews, v. 130, p. 86-102.

Condie, K. C., 1991, Another look at rare earth elements in shales: Geochimica et Cosmochimica Acta, v. 55, no. 9, p. 2527-2531.

Cullers, R. L., 1995, The controls on the major-and trace-element evolution of shales, siltstones and sandstones of Ordovician to Tertiary age in the Wet Mountains region, Colorado, USA: Chemical Geology, v. 123, no. 1, p. 107-131.

Deloule E, Alexandrov P, Cheilletz A, Laumonier B, Barbey P., 2002, In situ U/Pb zircon ages for Early Ordovician magmatism in the eastern Pyrenees, France: the Canigou orthogneisses: International Journal of Earth Sciences, v. 91, p. 398-405.

Ettensohn, F. R., Barron, L. S., 1981, Depositional model for the Devonian-Mississippian blackshale sequence of North America a tectono-climatic approach: U.S. Dept. of Energy. Morgantown Energy Technology Center, 80 pages.

Ettensohn, F. R., 1985, The Catskill delta complex and the Acadian orogeny: A model: Geological Society of America Special Papers, v. 201, p. 39-50.

Ettensohn, F. R., 1987, Rates of relative plate motion during the Acadian orogeny based on the spatial distribution of black shales: The Journal of Geology, p. 572-582.

Galy V., France-Lanord C., Beyssac O., Faure P., Kudrass H. and Palhol F., 2007, Efficient organic carbon burial in the Bengal fan sustained by the Himalayan erosional system: Nature, v. 450, p. 407-410.

Hayashi, K.-I., Fujisawa, H., Holland, H. D., and Ohmoto, H., 1997, Geochemistry of 1.9 Ga sedimentary rocks from northeastern Labrador, Canada: Geochimica et Cosmochimica Acta, v. 61, no. 19, p. 4115-4137.

Hayward, J. M., 2012, Zircon Geochronology of Ash Beds in the Marcellus Shale of the Appalachian Basin, West Virginia University Libraries.

Hosterman, J. W., and Whitlow, S., 1981, Clay mineralogy of Devonian shales in the Appalachian Basin: Geological Survey, Open-File Report (U.S.); (United States), v. 81, 585 pages.

Ibach, L. E. J., 1982, Relationship between sedimentation rate and total organic carbon content in ancient marine sediments: AAPG Bulletin, v. 66, no. 2, p. 170-188. 
Jian, X., Guan, P., Zhang, W., and Feng, F., 2013, Geochemistry of Mesozoic and Cenozoic sediments in the northern Qaidam basin, northeastern Tibetan plateau: Implications for provenance and weathering: Chemical Geology, v. 360-361, p. 74-88.

Lash, G. G., and Blood, D. R., 2014, Organic matter accumulation, redox, and diagenetic history of the Marcellus Formation, southwestern Pennsylvania, Appalachian basin: Marine and Petroleum Geology, v. 57, p. 244-263.

McLennan, S. M., 1989, Rare earth elements in sedimentary rocks; influence of provenance and sedimentary processes: Reviews in Mineralogy and Geochemistry, v. 21, no. 1, p. 169200.

McLennan, S. M., 2001, Relationships between the trace element composition of sedimentary rocks and upper continental crust: Geochemistry, Geophysics, Geosystems, v. 2, no. 4.

McLennan, S. M., Nance, W., and Taylor, S., 1980a, Rare earth element-thorium correlations in sedimentary rocks, and the composition of the continental crust: Geochimica et Cosmochimica Acta, v. 44, no. 11, p. 1833-1839.

McLennan, S. M., Nance, W. B., and Taylor, S. R., 1980b, Rare earth element-thorium correlations in sedimentary rocks, and the composition of the continental crust: Geochimica et Cosmochimica Acta, v. 44, no. 11, p. 1833-1839.

Milliken, K. L., Rudnicki, M., Awwiller, D. N., and Zhang, T., 2013, Organic matter-hosted pore system, Marcellus formation (Devonian), Pennsylvania: AAPG bulletin, v. 97, no. 2, p. 177-200.

Moune, S., and Gauthier, P. J., Gislason, S. R, and Sigmarsson, O., 2006, Trace element degassing and enrichment in the eruptive plume of the 2000 eruption of Hekla volcano, Iceland: Geochimica et Cosmochimica Acta, v. 70, p. 461-479.

Murphy, J. B., van Staal, C. R., and Keppie, J. D., 1999, Middle to late Paleozoic Acadian orogeny in the northern Appalachians: A Laramide-style plume-modified orogeny?: Geology, v. 27, no. 7, p. 653-656.

Murray, R.W, Leinen. M., 1996, Scavenged excess aluminum and its relationship to bulk titanium in biogenic sediment from the central equatorial Pacific Ocean: Geochimica et Cosmochimica Acta, v. 60, p. 3869-3878.

Nesbitt, H., and Young, G., 1982, Early Proterozoic climates and plate motions inferred from major element chemistry of lutites: Nature, v. 299, no. 5885, p. 715-717.

Paikaray, S., Banerjee, S., and Mukherji, S., 2008, Geochemistry of shales from the Paleoproterozoic to Neoproterozoic Vindhyan Supergroup: Implications on provenance, tectonics and paleoweathering: Journal of Asian Earth Sciences, v. 32, no. 1, p. 34-48. 
Parrish, C. B., 2013, Insights into the Appalachian Basin Middle Devonian Depositional System from U-Pb Zircon Geochronology of Volcanic Ashes in the Marcellus Shale and Onondaga Limestone, West Virginia University.

Pedersen, T. F., and Calvert, S. E., 1990, Anoxia vs productivity; what controls the formation of organic-carbon-rich sediments and sedimentary rocks?: AAPG Bulletin, v. 74, no. 4, p. 454-466.

Rare Earth Element Database, National Energy Technology Laboratory, US Department of Energy, accessed on 04/2016, https://edx.netl.doe.gov/ree/

Rast, N., and Skehan, J. W., 1993, Mid-Paleozoic orogenesis in the North Atlantic: the Acadian orogeny: Geological Society of America Special Papers, v. 275, p. 1-26.

Rimmer, S. M., Thompson, J. A., Goodnight, S. A., and Robl, T. L., 2004, Multiple controls on the preservation of organic matter in Devonian-Mississippian marine black shales: geochemical and petrographic evidence: Palaeogeography, Palaeoclimatology, Palaeoecology, v. 215, no. 1-2, p. 125-154.

Sageman, B. B., Murphy, A. E., Werne, J. P., Ver Straeten, C. A., Hollander, D. J., and Lyons, T. W., 2003, A tale of shales: the relative roles of production, decomposition, and dilution in the accumulation of organic-rich strata, Middle-Upper Devonian, Appalachian basin: Chemical Geology, v. 195, no. 1, p. 229-273.

Taylor, S. R., and McLennan, S. M., 1995, The geochemical evolution of the continental crust: Reviews of Geophysics, v. 33, no. 2, p. 241-265.

Totten, M. W., and Hanan, M. A., 1998, The accessory-mineral fraction of mudrocks and its significance for whole-rock trace-element geochemistry: Shales and mudstones, v. 2, p. $35-53$.

Van Staal, C., Dewey, J., Mac Niocaill, C., and McKerrow, W., 1998, The Cambrian-Silurian tectonic evolution of the northern Appalachians and British Caledonides: history of a complex, west and southwest Pacific-type segment of Iapetus: Geological Society, London, Special Publications, v. 143, no. 1, p. 197-242.

Ver Straeten, C. A., 2005, Volcanic ash preservation/stratinomy in marine and lacustrine settings: Biases of processes and scale, in Proceedings Geological Society of America Abstracts with Programs, Volume 37, p. 74.

Ver Straeten, C. A., 2008, Volcanic tephra bed formation and condensation processes: a review and examination from Devonian stratigraphic sequences: The Journal of Geology, v. 116, no. 6 , p. 545-557.

Ver Straeten, C. A., 2009, The classic Devonian of the Catskill Front: A foreland basin record of Acadian orogenesis, in Proceedings New York State Geological Association Field Trip Guidebook 81st Annual Meeting, p. 7-1. 
594

595

596

597

598

599

600

601

602

603

604
Ver Straeten, C. A., 2010, Lessons from the forland basin: Nothern Applachian basin perspectives on the Acadian orogeny: Geological Society of America Memoir, v. 206, p. 251-282.

Werne, J. P., Sageman, B. B., Lyons, T. W., and Hollander, D. J., 2002, An integrated assessment of a "type euxinic" deposit: evidence for multiple controls on black shale deposition in the Middle Devonian Oatka Creek Formation: American Journal of Science, v. 302, no. 2 , p. 110-143. 